ON THE RECORD

(CWe can categorically state that we have not released man-eating badgers into the area.")

UK military spokesman Major Mike Shearer denies rumours that British forces had sowed panic in Basra, Iraq, by unleashing ferocious honey badgers (pictured). The badgers, slightly larger and scarier than the British woodland version, are in fact indigenous to the Middle East.

\section{SHOWBIZ NEWS}

\section{We will doc you}

Former Queen guitarist Brian May has finally completed the astrophysics $\mathrm{PhD}$ he abandoned 33 years ago after becoming distracted by international superstardom. He has submitted his thesis to Imperial College, London, and is set to become $\mathrm{Dr}$ May in May next year. Rock ' $n$ ' roll.

\section{ZOO NEWS}

\section{Bear burnout}

Berlin Zoo's Thomas Dörflein, who found fame as the keeper of Knut, the world's cutest bear ${ }^{\mathrm{TM}}$, has bowed out of the limelight. He has retired from public play sessions with the young polar bear, who now weighs 50 kilograms and is becoming a bit of a handful.

\section{ROBOT NEWS}

\section{Jesus-bot}

Engineers at Carnegie Mellon University in Pittsburgh, Pennsylvania, say they have created the first robot that can walk on water. Unfortunately, it can carry a load of only 9.3 grams.

\section{ZOO/ROBOT NEWS}

\section{Lamprey power}

Roboteers led by Ferdinando Mussa-Ivaldi of Northwestern University in Evanston, Illinois, have created a cyborg that uses a lamprey brain to control a lightseeking robotic disc. They hope it could lead to prosthetic aids for people paralysed by stroke or motor neurone disease.

Sources: BBC, The Times, CNN, PhysOrg, Small Times

\title{
US proposal for carbon cuts offers compromise
}

Legislation to cut carbon emissions has traditionally received little support in corporate boardrooms and union halls, but this may soon change. Several large utility companies are among those backing a new proposal offered in the US Congress on 11 July by Senators Jeff Bingaman (Democrat, New Mexico) and Arlen Specter (Republican, Pennsylvania).

The Bingaman-Specter proposal is the latest of several major climate bills now under consideration by Congress (see table). Some observers see this one as setting the tone for a compromise package aiming to bring together competing interests to fight climate change. The 'Low Carbon Economy Act' would require the United States to reduce its carbon output to 2006 levels by 2020 and to 1990 levels by 2030 . (The Kyoto Protocol on climate change, which the United States has not ratified, calls for cuts below 1990 levels by 2012.) Further reductions, to at least $60 \%$ below 2006 levels by 2050 , are contingent upon cuts being made by other countries.

Companies such as Duke Energy, one of the nation's largest utility suppliers, back the new bill because it includes a provision allowing carbon emitters to buy extra allowances at a set cost. This would provide a 'safety valve', ensuring a stable price for emissions, and keeping the companies' future costs at a foreseeable level.

The bill also has the support of the union group AFL-CIO, which has traditionally

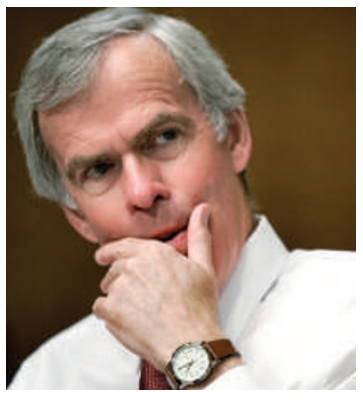

Jeff Bingaman's climate bill has industry backing. challenged climate-control legislation on the grounds that it would drive jobs overseas, and key Republican legislators - such as Lisa Murkowski and Ted Stevens, both senators from Alaska - who have been sceptical of other climate proposals. "The other bills are more aggressive and less realistic," says Frank Maisano, a spokesman in Washington DC for Bracewell \& Giuliani, a law firm representing many of the fossil-fuel industries. "They're all show and no go."

But environmental advocates say that pricing extra allowances at a set cost will weaken the nascent American carbon market. "I think it's unlikely to achieve absolute reduction if the safety valve undercuts the programme," says Vicki Arroyo, director of policy analysis at the Pew Center on Global Climate Change in Arlington, Virginia. "It's more like an escape hatch."

\section{Get practical, urge climatologists}

British experts have criticized the focus of current climate projections. They say that scientists should shift from models that predict what will happen many decades from now, and concentrate instead on shorter-term forecasts that will aid policy-makers, businesses and the public.

Climate models such as those used in the Intergovernmental Panel on Climate Change (IPCC) reports have been instrumental in convincing the world that climate change threatens ecosystems and human societies, but they do not provide much practical guidance. "We may not be providing what we possibly could," says Peter Cox, a climate modeller at the University of Exeter, UK, and former chair of climate-system dynamics at the UK Met Office.

Cox and his colleague David Stephenson, also at the University of Exeter, published their argument last week (P. Cox and D. Stephenson Science 317, 207-208; 2007). “The IPCC has nailed many old questions," says Cox. "It's a done deal, so we had better move on."
A key question is how to make climate-change models socially relevant. Cox and Stephenson propose having climate forecasters shift their attention to around 2050, rather than trying to predict farther into the future. This would effectively mean that the timescale of climate predictions would match that over which long-term policy and business planning is carried out.

The authors note that climate models are least uncertain for between 30 and 50 years from now. Shorter-term predictions will be less accurate because of 
CLIMATE BILLS IN CONGRESS

\begin{tabular}{|c|c|c|c|c|c|}
\hline \multirow[b]{2}{*}{ Provisions } & \multicolumn{5}{|c|}{ Sponsors } \\
\hline & Bingaman-Specter & Lieberman-McCain & Sanders-Boxer & Feinstein ${ }^{\star}$ & Kerry-Snowe \\
\hline $\begin{array}{l}\text { Emission } \\
\text { target } \\
\text { by } 2050\end{array}$ & $\begin{array}{l}60 \% \text { below } 2006 \text { levels } \\
\text { - provided other countries } \\
\text { play ball }\end{array}$ & $60 \%$ below 1990 levels & $80 \%$ below 1990 levels & $\begin{array}{l}\text { Cut expected levels for } \\
2020 \text { by } 25 \% ; 1.5 \% \text { annual } \\
\text { reductions thereafter }\end{array}$ & $65 \%$ of 2000 levels \\
\hline $\begin{array}{l}\text { Carbon } \\
\text { allowance }\end{array}$ & $\begin{array}{l}53 \% \text { to industry; } 24 \% \text { for } \\
\text { auction; } 9 \% \text { to states; } \\
14 \% \text { to others }\end{array}$ & $\begin{array}{l}\text { Allowances distributed across } \\
\text { sectors and to a new 'Climate } \\
\text { Change Credit Corporation' }\end{array}$ & $\begin{array}{l}\text { Awarded to those most } \\
\text { affected by transition to a } \\
\text { carbon-free economy }\end{array}$ & $\begin{array}{l}\text { Allowances based on } \\
\text { means of electricity } \\
\text { generation }\end{array}$ & $\begin{array}{l}\text { To be determined by the } \\
\text { president }\end{array}$ \\
\hline $\begin{array}{l}\text { Technology } \\
\text { support }\end{array}$ & $\begin{array}{l}\text { Creates fund for } \\
\text { research into low-carbon } \\
\text { technologies and vehicles. } \\
\text { Supports carbon capture } \\
\text { and storage }\end{array}$ & $\begin{array}{l}\text { Climate Technology Finance Board } \\
\text { backs public-private research } \\
\text { partnerships. Climate Change } \\
\text { Credit Corporation supports low- } \\
\text { carbon technologies }\end{array}$ & $\begin{array}{l}\text { Grants for carbon capture and } \\
\text { storage projects. Recommends } \\
\text { boosting R\&D for low-carbon } \\
\text { technologies by } 100 \% \text { a year } \\
\text { for a decade }\end{array}$ & $\begin{array}{l}\text { Climate Action Trust } \\
\text { Fund established to } \\
\text { commercialize new low- } \\
\text { carbon technologies }\end{array}$ & $\begin{array}{l}\text { Recommends boosting R\&D } \\
\text { by } 100 \% \text { a year for a decade. } \\
\text { Creates programme to assist } \\
\text { with adaptation to climate } \\
\text { variation }\end{array}$ \\
\hline
\end{tabular}

Under the bill, $53 \%$ of carbon allowances would be handed out to utilities, manufacturers and other carbon-producing industries. From 2017 on, an increasing proportion of allowances would be auctioned off, generating billions of dollars for green technology and climate-change adaptation. The safety valve would start at $\$ 12$ per tonne of carbon dioxide emitted, and would increase each year at 5\% above inflation.

The Bingaman-Specter bill also packs in several features that don't appear in other proposed legislation, says Jonathan Pershing, a climate expert at the World Resources Institute, an environmental think-tank in Washington DC. It provides additional allowances for companies that invest in carbon capture and storage, and spells out how the government will divvy out carbon allowances, including a share for states to distribute. "None of the other bills has this," Pershing says.

The major sticking point for environmental groups is the bill's safety valve. If the market price for carbon exceeds the safety valve, emitters can instead buy allowances - essentially a carbon tax. The cost of credits is likely to surpass the limit early on and disrupt the carbon market, says Arroyo.

Such a feature would also complicate US participation in an international carbon-trading market. European governments are unlikely to allow companies to purchase American offsets directly, but a less formal link-up based on options trading could emerge, says Pershing. The European carbon market, which opened in 2005, has got off to a shaky start. Prices for a tonne of carbon plummeted from $€ 31$ (US\$43) to $€ 12$ in April 2006, when leaked emissions data revealed that several nations hadn't used up their allotted credits.

Jeff Holmstead, former head of the Environmental Protection Agency's Office of Air and Radiation and now also with Bracewell \& Giuliani, says a safety valve is needed because technologies to make deep cuts in carbon emissions are not yet available.

Larger questions about effects on the domestic economy and the likely migration of carbon-producing industries abroad mean climate legislation has no prospect of passing soon, Holmstead argues. He is confident that there will be insufficient votes supporting it in either the House of Representatives or the Senate "until there's a much better understanding of what it will mean".

Those pushing for a strong climate bill are more optimistic. Congress is likely to act soon, says Pershing, given the growing pressure from the US public to address global warming. "The question is not whether, but when," he says.

A subcommittee led by Senators Joe Lieberman (Independent, Connecticut) and John Warner (Republican, Virginia) is expected to work out a compromise climate bill that is likely to reach the Senate floor in coming months. Ewen Callaway uncertainty over initial conditions. Changes that will transpire over the next three decades are essentially "already in the system", says Cox. For predictions more than 50 years

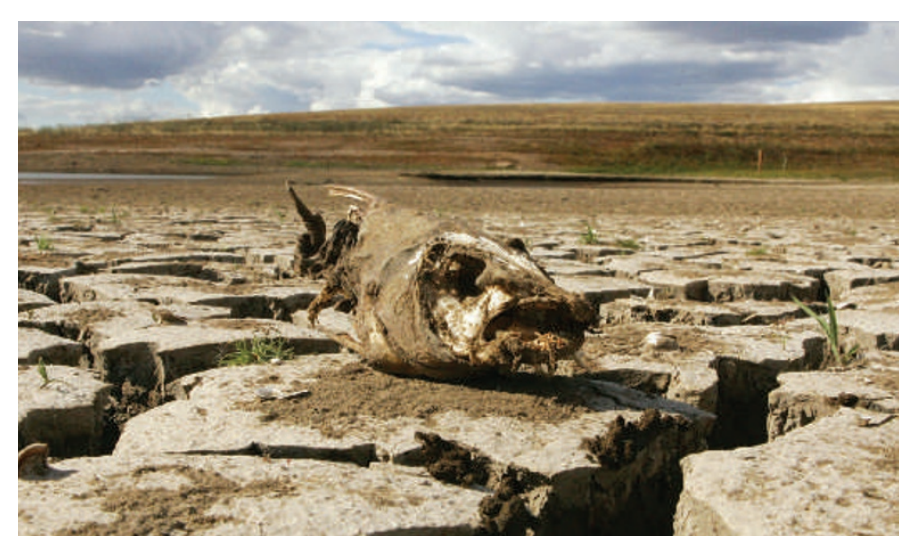

Out of water: practical solutions are needed to the problems of climate change.

in the future, uncertainty levels in the models increase because no one can accurately forecast the level of carbon dioxide emissions resulting from human activity.
Between 30 and 50 years away is thus a sort of sweet spot in which to target policy planning, Cox says. Mitigation policies and plans for associated socioeconomic factors, such as economic growth, energy use and technology needs, could be developed with that time frame in mind.

Some of those involved in the IPCC process do not disagree in principle, but say the inherent uncertainty of climate models will always make forecasting difficult. "Focusing on what 'should be' is a worthy goal going forward, but not a panacea for the uncertainty problem," says Cynthia Rosenzweig, a climate modeller at NASA's Goddard Institute for Space Studies in New York, and a coordinating lead author of the most recent IPCC review, published this year.

Another report released last week also criticizes the "big gap" between how climate scenarios are currently used and their "potential contributions" to policy making.

The report was co-authored by Rosenzweig, and is the second in a series by the US Climate Change Science Program.

The current generation of climate scenarios is still useful for resource managers to guide their preparation for climate change over the next few decades. Planning for such change is becoming "mainstream" in water-management systems, coasts and human health care, says Rosenzweig.

Quirin Schiermeier 